\title{
RISK ANALYSIS OF TOLL ROAD ACCIDENT USING FMEA AND AHP METHODS
}

\author{
Edelweis Gent Haryantoํㅜ, Eva Azhra Latifa² \\ ${ }^{1,2}$ Civil Engineering Department, Politeknik Negeri Jakarta, Jl. Prof. DR. G.A. Siwabessy, Depok, Jawa \\ Barat 16424 \\ e-mail : edelweisgent17@gmail.com ${ }^{1}$; evaazhra@gmail.com ${ }^{2}$
}

\begin{abstract}
Road accidents are one of the leading causes of death in the world. It is not only the victims that killed or seriously injured, but accidents significantly affected the quality of life of the people as well as economic and social development in the country. However, the threat of road accidents has not been fully recognized, and has not been well studied even though it is one of the most frequent causes of human death and loss of property. This research was conducted to determine the causes of accidents on the toll road with the FMEA method (Failure Mode Effect Analysis) which is divided into 3 factors: human factors, vehicle factors, and road factors. After that, determining the alternative solutions for dealing with accidents on toll roads using the Analytical Hierarchy Process based on 3 criteria: cost, time and impact. The results showed that based on FMEA analysis, the highest risk factors were found to be human factors caused by negligence. Based on risk factors due to negligence, the results of $A H P$ analysis are: the impact criteria as the main criteria with a weight value of 0.77 , and the chosen alternative solution is the fulfillment of functional feasibility with global weight 0.42. Fulfillment of functional feasibility can be done by adding road equipment such as traffic signs and rumble stripe markers.
\end{abstract}

Keywords : AHP; FMEA; Risk Factor; Road Accident; Solution

\section{INTRODUCTION}

Road accidents become one of the leading causes of death in the world (WHO, 2018). It is not only the victims that killed or seriously injured, but accidents significantly affected the quality of life of the people as well as economic and social development in the country (Kompas, 2018). However, the threat of road accidents has not been fully recognized, and has not been well studied even though it is one of the most frequent causes of human death and loss of property (Gebru, 2017).

According to accident data from PT Citra Marga Nusaphala Persada on Jalan Ir. Wiyoto Wiyono, there were 683 accidents during 2018, and 59 of the accidents caused minor injuries to severe injuries (PT. Citra Marga Nusaphala Persada, 2018).
One of the commonly used risk analysis methods is the Failure Mode Effect Analysis (FMEA). FMEA has weakness that it cannot be used alone. This is because the FMEA method does not describe improvements to the risks that occur. The FMEA method only shows / illustrates the value of risk or failure of a process, so that additional methods are required as a tool to analyze recommendations for improvement. This weakness is complemented by the Analytical Hierarchy Process (AHP) method. AHP allows users to create different levels or hierarchies based on the complexity of the problem and determine the priority level based on the assessment of pairwise comparisons between each problem (Suciati, 2017).

This study aims to determine the causes of accidents on toll roads with the FMEA 
method and determine alternative solutions to overcome accidents on toll roads using the AHP method.

FMEA is a method of evaluating the possibility of a failure of a system, design, process or service to make the corrective action. In FMEA, every possible failure that occurs is quantified to make handling priority. Quantification of priority determination is based on the product of the frequency, damage level, and detection rate of risk (Nadeak, 2008).

AHP is an analytical method used to obtain the ratio scale of different pairs as well as continuous pair comparisons in a stratified hierarchical structure. AHP has special attention to the process of consistency, measurement of initiation and dependence within and between groups of elements in the structure. In solving problems with the AHP method there are some basic principles that must be understood (Febriani, 2018):

\section{Decomposition}

Decomposition is the main principle in the AHP method that describes or solves whole problems into elements that are translated into a hierarchy after defining the problems. To get accurate results, the solution is carried out on the elements so we get several levels of the problem to be solved (Latifah, 2005).

\section{Comparative assessment}

Comparative assessment aims to make judgments about the relative importance between two elements at a certain level in relation to the level above it. This assessment is the core of AHP because it will affect the priority of the elements. The results of this assessment are more easily presented in the form of a pairwise comparison matrix (Wicaksana, 2018).

\section{Synthesis of priorities}

In each pair comparison, i.e. compares each element with other elements at each level of the hierarchy in pairs so that the value of the element's importance level is obtained in the form of qualitative opinions. Pairwise comparisons are often used to determine the relative importance of the elements and the criteria for which pairwise comparisons are repeated for all elements in each level. High-weighted elements are decision choices that are worth considering, (Saaty \& Vargas, 2012).

\section{Consistency of logic}

Consistency has the first two meanings that similar objects can be grouped according to their diversity and relevance. The second is the level of relationship between objects based on certain criteria (Saaty T. L., 1986).

\section{METHODS}

The following are the stages in this study:

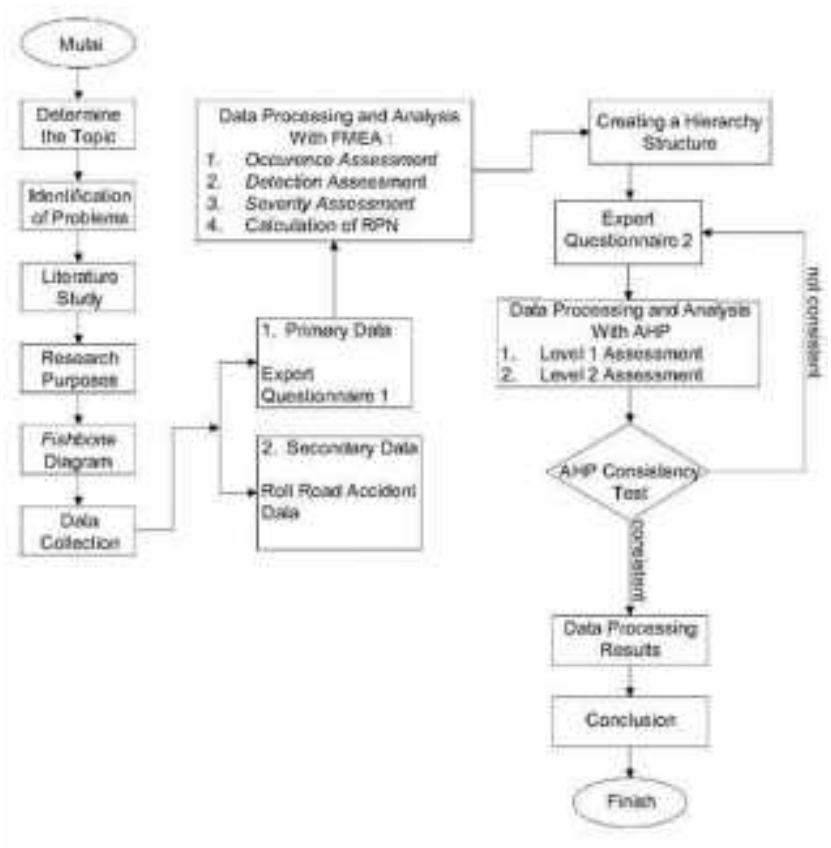

Figure 1. Flow Chart

\section{Method of Collecting Data}

This process is started by collecting data that needed to carry out the analysis at 
the next stage. There are two types of data collected, namely primary data and secondary data.

\section{Primary Data}

In this study the primary data used is data from questionnaire to experts in the field of land transportation originating from the academic, industrial and government using procedures found in the FMEA and AHP processes. The questionnaire was conducted twice. The first step is weighting risk factors on road accidents. The next stage is the weighting the criteria, and alternatives that have a major influence in reducing accidents on the toll road.

\section{Secondary Data}

Secondary data used in this study is not obtained from direct observation but obtained from the relevant agencies. In this study secondary data was obtained from PT. Citra Marga Nusaphala Persada Tbk.

\section{Analysis Method}

Questionnaire data obtained from experts related to risk analysis on toll roads are processed using the FMEA and AHP methods.

Road accident factors in the FMEA method can be seen in Table 1. The hierarchical structure of the AHP method can be seen in Figure 2 .

FMEA analysis started by collecting the questionnaires obtained based on predetermined factors and then carried out the data processing stages as follows: (a) Processing questionnaire data to determine the value of Severity, (b) Processing questionnaire data to determine Occurence value, (c) Processing questionnaire data to determine Detection value, (d) Processing questionnaire data to determine Risk Priority Number.
AHP analysis starts based on the biggest risk factor from the FMEA analysis which will be used as an objective in the AHP hierarchy.

In this study, the hierarchy used has 3 levels. Level 0 is the goal, level 1 is the criteria, and level 2 is an alternative solution. The goal at level 0 of this hierarchy is to reduce the level of human failure factors caused by negligence obtained from the results of the FMEA analysis. At level 1 consists of cost, time and impact criteria. At level 2, it consists of fulfillment of functional feasibility, fulfillment the safety requirements of motor vehicles, and enforcing traffic safety regulations.

The steps or procedures that must be carried out in the AHP method for solving a problem (Rimantho, Fathurohman, Cahyadi, \& Sodikun, 2017):

1. Defining the problem and desired solution

2. Hierarchical structure from a holistic perspective

3. Making a paired comparison matrix for the contribution or influence of each relevant element for each influential criterion at the level above it.

4. Getting all the considerations needed to develop the matrix device in step 3 .

5. After gathering all paired comparative data, priorities are sought and consistency is tested.

6. Carry out steps 3, 4 and 5 for all levels and clusters in the hierarchy.

7. Using a hierarchical composition (synthesis) to weight the priority vectors with the weight of the criteria

8. Evaluating consistency for the entire hierarchy. 


\section{RESULTS AND DISCUSSION}

\section{FMEA}

The results of the distribution of the questionnaire, the mode value of severity (S), occurrence (S) and detection (D) will be obtained to further obtain the RPN value. RPN value is a value that states the level of risk of a failure or cause of failure or cause of failure. The higher the RPN value, the higher the risk of failure. The RPN Priority Value can be seen in Table 2 .

Based on the RPN value from the results of the FMEA analysis it is known that humans are the highest risk factor were found to be human factor caused by negligence. The results of the FMEA analysis are in accordance with the sample accident data on the Ir. Wiyoto Wiyono belongs to Citra Marga Nusaphala Persada.

Accident factor because of negligence has a RPN 900 value with a very high category. The results of this analysis are also in accordance with the existing accident data, it is necessary to need a solution to deal with this very high risk of accidents. The determination of the alternative solution from the FMEA analysis will be carried out by the AHP method.

\section{AHP}

The results of alternative selection priority weights in the AHP method can be seen in table 3 .

Globally, the biggest weighted criteria ranking is impact with a weight of 0.77 , which means that for the selection of alternative solutions due to negligent factors, the impact criteria are the most important criteria. Furthermore, the biggest weight value of the alternative is the fulfillment of functional feasibility with a weight value of 0.42 . Fulfillment of functional feasibility of road functions is an alternative solution chosen to reduce accident rates due to negligence factors on toll roads.

Fulfillment of functional feasibility of road functions is choosen to reduce accidents due to human factors caused by negligence. Technical requirements for road worthy performance according to Permen PU No. 11 / PRT / M / 2010 consist of road geometry, pavement, utilization of road parts, road equipment, and traffic engineering management. In toll road conditions, where existing roads have good function-worth conditions, to reduce the risk of accidents due to careless factors, it can be done by adding road equipment such as traffic signs and rumble stripe markers.

\section{CONCLUSION}

The results of the accident risk analysis on the toll road using the Effect Failure and Analysis Mode (FMEA) method showed that the highest risk factor were found to be human factor caused by negligence.

The results of AHP analysis can be concluded that the impact is the criterion which has the highest value with a weight value of 0.77 and the alternative solution with the highest value is the fulfillment of roadworthiness function requirements with a global weight value of 0.42. Fulfillment of functional feasibility can be done by adding road equipment such as traffic signs and rumble stripe markers.

\section{REFERENCES}

Febriani, R. D. (2018). Kajian Metode Analytical Hierarchy Process (AHP) Untuk Optimisasi Proses Seleksi Pinjaman Modal Usaha 
Bagi Nasabah. Medan: Universitas Sumatera Utara.

Gebru, M. K. (2017). Road traffic accident: Human security perspective. International Journal of Peace and Development Studies, 8(2), 1524.

Kompas. (2018, September 21). Tingginya Kecelakaan Lalu Lintas Bikin Negara Merugi. Dipetik August 27, 2019, dari https://otomotif.kompas.com/rea d/2018/09/21/200029115/tinggi nya-kecelakaan-lalu-lintasbikin-negara-merugi

Latifah, S. (2005). Prinsip-Prinsip Dasar Analytical Hierarachy Process. Jurnal kehutanan dan pertanian, 1- 3.

Nadeak, N. Y. (2008). Analisis Risiko Pada Kegagalan Pemeliharaan dan Operasi Pada Sistem Turbin Gas PLTGU dengan Metode FMEA dan FTA. Depok: Fakultas Teknik Universitas Indonesia.

PT. Citra Marga Nusaphala Persada. (2018). Data Kecelakaan 20152018. Jakarta.

Rimantho, D., Fathurohman, Cahyadi, B., \& Sodikun. (2017). Pemilihan Supplier Rubber Parts Dengan Metode Analytical Hierarchy Process Di PT.XYZ. Jurnal Rekayasa Sistem Industri, 6 No.2, 93-104.

Saaty, T. L. (1986). Pengambilan Keputusan Bagi Para PemimpinProses Hirarki Analitik Untuk Pengambilan Keputusan Dalam Situasi yang Kompleks. Pittsburgh: IPPM.

Saaty, T. L., \& Vargas, L. G. (2012). Model, Methods, Concepts \& Application of the Analitic Hierarchy Process. Philadelphia: Springer.
Suciati, S. (2017). Analisa Kelaikan Fungsi Jalan Berdasarkan Pendekatan Kuantitif AHP. Teknik Sipil Siklus, Vol. 3, 3-4.

WHO. (2018, December 7). Road traffic injuries. Dipetik August 27, 2019, dari https://www.who.int/newsroom/fact-sheets/detail/roadtraffic-injuries

Wicaksana, C. (2018). Pemilihan Pagar Pengaman Jalan Tol Menggunakan Metode AHP. Depok: Teknik Sipil Politeknik Negeri Jakarta. 
Applied Research on Civil Engineering and Environment (ARCEE) VOL. 01 NO. 02, February 2020

\section{Appendix}

Table 1. Accident Factors

\begin{tabular}{|c|c|c|c|c|}
\hline No & $\begin{array}{c}\text { Component and } \\
\text { Function } \\
\end{array}$ & $\begin{array}{l}\text { Potential Failure } \\
\text { Mode }\end{array}$ & Potential Effect(s) of Failure & $\begin{array}{l}\text { Potential Cause(s) of } \\
\text { Failure }\end{array}$ \\
\hline \multirow{10}{*}{1} & \multirow{10}{*}{ Human } & \multirow{5}{*}{ Physiological } & \multirow{5}{*}{$\begin{array}{l}\text { Accidents Due to Failure of } \\
\text { Physiological Factor }\end{array}$} & Vision \\
\hline & & & & Hearing \\
\hline & & & & Disease \\
\hline & & & & Fatigue \\
\hline & & & & Effects of drugs \\
\hline & & \multirow{5}{*}{ Psychological } & \multirow{5}{*}{$\begin{array}{l}\text { Accidents Due to Failure of } \\
\text { Psychological Factor }\end{array}$} & Age \\
\hline & & & & Gender \\
\hline & & & & Education \\
\hline & & & & Negligence \\
\hline & & & & Undisciplined \\
\hline \multirow{13}{*}{2} & \multirow{13}{*}{ Vehicle } & \multirow{9}{*}{ Technical Standards } & \multirow{9}{*}{$\begin{array}{l}\text { Accidents Due to Failure of } \\
\text { Technical Factors }\end{array}$} & Steering wheel \\
\hline & & & & Tire \\
\hline & & & & Brake \\
\hline & & & & Machine \\
\hline & & & & Vehicle age \\
\hline & & & & Suspension \\
\hline & & & & electrical \\
\hline & & & & Vehicle Lights \\
\hline & & & & Rear view mirror \\
\hline & & \multirow{4}{*}{ Safety Standards } & \multirow{4}{*}{$\begin{array}{c}\text { Accidents Due to Failure of } \\
\text { Safety Standards }\end{array}$} & Vehicle windshield \\
\hline & & & & Safety belt \\
\hline & & & & Load Load \\
\hline & & & & Speed \\
\hline \multirow{8}{*}{3} & \multirow{8}{*}{ Road } & \multirow{4}{*}{ Geometry } & \multirow{4}{*}{$\begin{array}{l}\text { Accidents Due to Failure of } \\
\text { Geometric Factors }\end{array}$} & Alignment \\
\hline & & & & Road Conditions \\
\hline & & & & Signs / Markers \\
\hline & & & & Super elevation \\
\hline & & \multirow{4}{*}{ Environment } & \multirow{4}{*}{$\begin{array}{l}\text { Accidents Due to Failure of } \\
\text { Environmental Factors }\end{array}$} & Smog \\
\hline & & & & Rain \\
\hline & & & & Lighting \\
\hline & & & & Traffic density \\
\hline
\end{tabular}

Table 2. RPN

\begin{tabular}{|c|c|c|}
\hline $\begin{array}{c}\text { Potential Cause(s) of } \\
\text { Failure }\end{array}$ & RPN & Kategori \\
\hline Negligence & 900 & Very High \\
\hline Fatigue & 810 & Very High \\
\hline Vision & 450 & Moderate - High (MH) \\
\hline Disease & 288 & Moderate (M) \\
\hline Load Load & 192 & Low Moderate (LM) \\
\hline Effects of drugs & 180 & Low Moderate (LM) \\
\hline Speed & 160 & Low Moderate (LM) \\
\hline Tire & 144 & Low (L) \\
\hline Undisciplined & 144 & Low (L) \\
\hline Hearing & 144 & Low (L) \\
\hline Vehicle Lights & 100 & Very Low - Low (VL-L) \\
\hline Vehicle age & 90 & Very Low - Low (VL-L) \\
\hline Education & 90 & Very Low - Low (VL-L) \\
\hline Smog & 80 & Very Low - Low (VL-L) \\
\hline Brake & 72 & Very Low - Low (VL-L) \\
\hline Suspension & 60 & Very Low - Low (VL-L) \\
\hline Age & 56 & Very Low - Low (VL-L) \\
\hline Machine & 48 & Very Low (VL) \\
\hline Rain & 48 & Very Low (VL) \\
\hline Steering wheel & 40 & Very Low (VL) \\
\hline Safety belt & 36 & Very Low (VL) \\
\hline Road Conditions & 36 & Very Low (VL) \\
\hline Vehicle windshield & 24 & Very Low (VL) \\
\hline electrical & 16 & Very Low (VL) \\
\hline Lighting & 12 & Very Low (VL) \\
\hline Signs / Markers & 10 & Very Low (VL) \\
\hline Rear view mirror & 10 & Very Low (VL) \\
\hline Super elevation & 9 & Very Low (VL) \\
\hline Gender & 8 & Very Low (VL) \\
\hline Alignment & 5 & Very Low (VL) \\
\hline Traffic density & 1 & Very Low (VL) \\
\hline
\end{tabular}

Table 3. Criteria and Alternative Value

\begin{tabular}{cccccc}
\hline & & \multicolumn{4}{c}{ Global Value } \\
\cline { 3 - 6 } Criteria & $\begin{array}{c}\text { Criteria } \\
\text { Value }\end{array}$ & Ranking & $\begin{array}{c}\text { Fulfillment of } \\
\text { functional feasibility }\end{array}$ & $\begin{array}{c}\text { Fulfillment the } \\
\text { Safety } \\
\text { Requirements of } \\
\text { Motor Vehicles }\end{array}$ & $\begin{array}{c}\text { Enforcing } \\
\text { Traffic Safety } \\
\text { Regulations }\end{array}$ \\
\hline Cost & 0,1 & 3 & 0,03 & 0,03 & 0,05 \\
Time & 0,13 & 2 & 0,02 & 0,03 & 0,07 \\
Impact & 0,77 & 1 & 0,38 & 0,14 & 0,25 \\
\hline Total & 1 & & 0,42 & 0,2 & 0,38 \\
\hline & Ranking & 1 & 3 & 2 \\
\hline
\end{tabular}




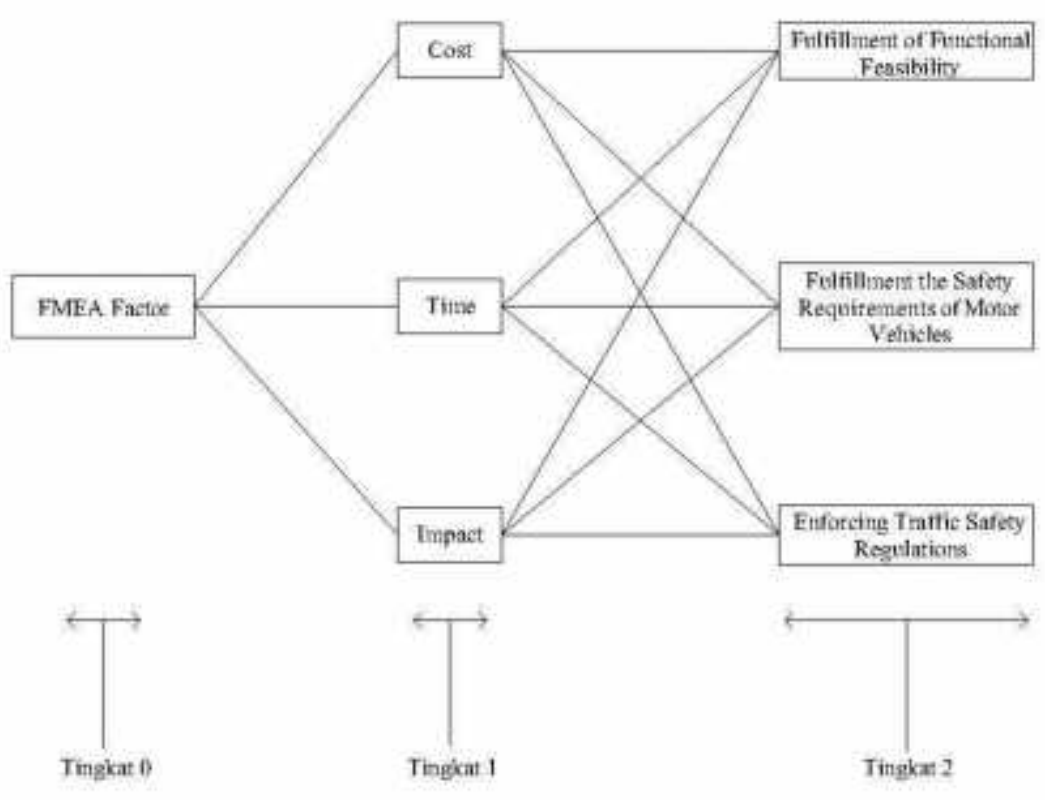

Figure 2. AHP Hierarchy 